\title{
RELIGIOUS AND NEAR-DEATH EXPERIENCE IN RELATION TO BELIEF IN A FUTURE LIFE
}

\author{
PROFESSOR PAUL BADHAM
}

\author{
This paper first appeared in the journal Mortality Vol 2, No 1, 1997 \\ published by Carfax, P.O. Box 25, Abingdon, OX14 3UE \\ and is reprinted with their permission.
}

\begin{abstract}
Christian belief in a future life was historically based on theistic religious experience. Today Near-death Experiences (NDEs) are more often cited. Exceptional reports of NDEs go back to the dawn of history but modern medicine has democratised them. Accounts from St Paul, St John of the Cross, and from Tibetan and Japanese Buddhism are described and compared with a large survey of contemporary experiences.
\end{abstract}

The author pleads the desirability of establishing a prospective research project to determine the objectivity of some of the experiences claimed.

\section{The Primacy of Experience in Religious Believing}

Claims to personal experience seem to be at the heart of religion. For although some come to belief by inheritance, some by acceptance of a revelation-tradition, and some by rational argument, the belief remains at "second-hand" until it has been appropriated through some kind of personal awareness. Only when faith is thought to have a real basis in the experience of the individual can it be said to be existentially real to the believer. In contemporary philosophy of religion, such experience is given a key role in that, in a religiously ambiguous world, which can be interpreted theistically or atheistically, it is the additional data of personal religious experience which for the believer tips the balance in favour of theism. ${ }^{1}$

In this context beliefs about a future life might seem to be an exception for, apart from Christian claims concerning Jesus Christ, no one who has totally died has returned to give assurance of a future hope, and it might seem therefore that of necessity this must be one belief that is forever without an experiential foundation. The purpose of this paper is to argue that this is not the case. Though there is no direct evidence of a future life, there are features both in religious experience, and increasingly today in near-death experience, which do provide an experiential foundation for a future hope. 


\section{Experience and the Finality of Death}

Normal everyday human experience has always pointed to the view that death is the end of any meaningful personal existence. This is very forcefully expressed in the Old Testament; "We must all die. We are like water spilt on the ground which cannot be gathered again". "Human beings perish for ever like their own dung." They are "of dust and will return to dust". In the grave they will rot away "with maggots beneath and worms on top". "In that same hour all thinking ends" 2 . It is true of course that for a generation or two the dead will live on in some kind of shadowy half-life in the memories of those who knew them.

John Bowker argues that such memory traces explain why so many ancient cultures had a notion of the dead having some kind of thin, insubstantial, shadowy existence underground (the Hebrew Sheol or Greek Hades). But in neither Ancient Greece, Mesopotamia, India, China or Israel was there any notion that life in this 'underworld' had any real significance or substance. There was "nothing after death to which one could look forward ... For our ancestors, there was definitely no future in dying" ${ }^{\prime 3}$. In the face of this universal human experience of death as the ending of personal life, how is it that notions of a 'real' life after death ever got off the ground at all? To answer this question we need to look at those features of human experience which, as a matter of historical fact, did lead to the emergence of such beliefs.

\section{The Experiential Basis for Belief in a Future Life in the Judeo-Christian Tradition}

Ancient Israel is a dramatic example of how beliefs can change in the light of new experiences. As we have already seen, the classic position in ancient Israel was that death must mean extinction because human beings are irreducibly physical entities who are totally at one with nature. They "have no advantage over the beasts" and are "like the grass that withers and the flowers that fade" ${ }^{\prime \prime}$. However, in spite of this a firm belief in a future life gradually evolved as religious experience came to be understood in personal terms. What appears to have happened is that conviction of a future hope grew out of beliefs of individuals who could enjoy a personal relationship with God. This was not the original form of early Judaism, which at first thought only of a relationship between God and the whole nation of Israel. But from the time of the exile in Babylon onwards (from $597 \mathrm{BCE}$ ) the idea of a covenant between God and humanity was increasingly seen in individualistic terms. As that conviction developed, so the thought of Israel moved along a path which led to the flowering of the future hope in the inter-testamental period. As Wheeler Robinson puts it, "The faith of the Old Testament logically points towards a life beyond death, because it is so sure of an inviolable fellowship with God" ${ }^{\prime 5}$.

The foundation for the faith ultimately arrived at was the conviction that, if human persons can really enjoy a personal relationship with God which God values, and if the believer really matters as a unique individual to the all-powerful and all-loving God, then God will not allow that individual and that relationship to be destroyed by death. Throughout the subsequent history of monotheism this conviction has remained dominant. As Edward Schillebeeckx argued: "The breeding ground of belief in life after death ... was always seen in a communion of life between God and man... Living communion with God, attested as the meaning, the foundation, and the inspiring content of human existence, is the only climate in which the believer's trust in life after death comes, and evidently can come to historical fruition"6. We shall see later that this is not wholly correct, in that belief in a future destiny has also come into being in some Buddhist cultures. But within the Jewish, Christian and Islamic cultures, Schillebeeckx is undoubtedly right that the experience of a direct encounter between God 
and the individual soul has been the prime foundation for assurance that death can never triumph over that divine love.

\section{The Claim to have Experience of 'the Risen Christ'}

Within the Christian tradition the belief of knowing God, held in common with Judaism and Islam, has been supplemented by a conviction that the death and resurrection of Jesus provides further ground for confidence in a future hope. For many Christians faith in the resurrection of Jesus is a faith based on historical considerations: namely that the disciples' experience of seeing the risen Christ was the fount and origin of Christianity. But from the time of St Athanasius onwards other Christians have asserted a more direct experiential base. ${ }^{7}$ They believe that Jesus rose from the dead because they claim to have come to know him directly as their personal saviour. For such Christians the primary experiential knowledge of the defeat of death is derived from this evangelical claim to know the risen Christ in their own lives.

\section{Religious Experience Today}

However, there is a problem for Christianity in contemporary Europe in that religious experiencing in its classic form does not appear to be anything like as prevalent as it once was. Many students of Religious Studies find difficulty with Otto's classic book The Idea of the Holy because the sense of the numinous - which Otto argued is the basis of religion seems to be something of which some have little experience. Otto assumed that a profound sense of awe and wonder at a fascinating and tremendous mystery, identified as the presence of the divine, was normative within Christian worship. But it does not appear any longer to be characteristic of contemporary Church life in modern Europe. The classic hymns of personal devotion display an intensity of religious feeling which goes beyond the more communal and social emphasis of much modern hymnody. And there is no longer the same expectation as there was in the past that ordinands would necessarily have felt a direct 'call' in the way Church tradition presupposes. This may be illustrated by the fact that in, current controversies over the ordination of women to the Christian priesthood, the argument from women's sense of being called by God to this ministry has not been given much weight.

It is of course true that a succession of empirical studies has shown that religious experience of a kind is far more widespread than often supposed. For example, in David Hay's Religious Experience Today it is claimed that as many as sixty-five per cent of postgraduate students of education in England had a religious experience which mattered to them. ${ }^{8}$ But in most of these cases the experience seemed very diffuse and hard to clarify. The main impression left from studying them is how non specific and vague they really were, and how different from the intense life-transforming experiences characteristic of classic conversion experience. Very few modem accounts describe the kind of personal relationship with God which historically formed a foundation for belief in a communion of love which not even death could end.

\section{Near-death Experiences}

In this context the recent upsurge in reports of near-death experience seems particularly important. This is often a profound and life-changing experience which people never forget. It shares many of the characteristics of the deepest religious experiences known to humanity, and yet, through the spread of modern resuscitation techniques, it has become available to hundreds of thousands of ordinary people. Twenty-five thousand such cases 
have now been collected from all over the world ${ }^{9}$ and, as medical technology advances, so every year does the number of people who have been resuscitated from apparent death. Of these a significant proportion - somewhere between ten and thirty-five per cent - have a series of vivid experiences. The experiences include reports of 'leaving the body', 'looking down on the resuscitation attempts', 'feeling a sense of life-review', 'meeting deceased relatives and friends' and enjoying a series of religious experiences of a mystical type including 'encounters' with a bright light sometimes perceived in personal terms and identified with a figure from the percipients' own religious traditions. The pattern of experiencing appears to be common across religious traditions, cultures and world-views though naturally the terminology used in the religious descriptions is culture specific.

\section{Earlier Accounts of Similar Experiences}

These experiences are not new. They go back to the dawn of human history and it seems likely that in many cultures they gave rise to a belief in the possibility of a future life. Mircea Eliade suggests that some ideas about life after death may have originated in Shamanistic trances which characteristically include a notion of the Shaman leaving his body. ${ }^{10}$ Daniel Van Egmond argues that "it is highly probable that some types of [religious] experience suggested to man that he is able to exist independently of his physical body. For instance, the so-called near-death experiences, out-of-the-body experiences and shamanistic trances are easily interpreted this way. Indeed, the occurrence of altered states of consciousness is such a common feature in most cultures that it is very probable that such experiences were interpreted as perceptions of so-called 'higher worlds'."11 Dean Shiels' research into out-ofthe-body experiences in primitive cultures showed that sixty-four of the sixty-seven cultures investigated believe in the reality of such states. He tested the conventional explanations given for such phenomena by western scholars and found that they did not apply in these cultures. His conclusion was that "When different cultures at different times and in different places arrive at the same or a very similar out-of-the-body-belief we begin to wonder if this results from a common experience of this happening." ${ }^{12}$

Most claims to out-of-the-body experience occur near the point of death. It seems likely therefore that it is the fact of such reported experiences which have given rise to the traditional description of death as "the moment when the soul leaves the body". The experience of simply watching a person die leads to a much simpler picture of death as "the moment when the person breathed-out (expired) for the last time". The fact that this description has been felt to need supplementation suggests that other facts of human experiencing have been given weight as well as what is most immediately apparent.

However in the past the distinctive near-death experience happened to only a tiny handful of people who had spontaneously recovered from apparent death, or who had - after much prayer, meditation, fast and vigil - seen comparable otherworldly visions. When such an unusual experience happened to someone, it was deemed to give that person very special authority on religious matters.

\section{St Paul's 'Out of the Body' Experience and heavenly Visions}

Consider for example the situation of St Paul. On what did his faith in the end ultimately depend? One's immediate response might be to cite 1 Corinthians 15 and his rehearsal there of the faith handed on to him. Yet it is intriguing that, when the Corinthians challenged St Paul's authority and asked him on what authority he spoke and acted, he did not appeal to 
the tradition he had received from others but instead felt impelled to describe his own foundational experience:

It may do no good but I must go on with my boasting; I come now to visions and revelations granted by the Lord. I know a Christian man who fourteen years ago (whether in the body or out of the body I don't know - God knows) was caught up as far as the third heaven. And I know that this same man, (whether in the body or apart from the body I don't know - God knows) was caught up into paradise, and heard words so secret that human lips may not repeat them. About such a man I am ready to boast. ${ }^{13}$

(2 Corinthians 12:1-5)

Few commentators doubt that St Paul was speaking autobiographically here - especially as a few verses later he laments that "to keep me from being unduly elated by the magnificence of such revelations I was given a thorn in the flesh ... to keep me from being too elated". ${ }^{14}$

What is intriguing for our present purpose is that St Paul's experience included out of the body experiences and visions of paradise, both of which are key features of the near-death experience.

Commenting on these verses in 2 Corinthians 12, St John of the Cross, the great 16th century mystic, remarked that such experiences normally only occur when the soul "goes forth from the flesh and departs this mortal life." But in St Paul's case he was allowed these visions by special grace. Such visions, however, occur "very rarely and to very few for God works such things only in those who are very strong in the spirit and in the law of God." ${ }^{\prime 15}$ St John of the Cross almost certainly had a comparable experience himself as evidenced by his poems where he speaks of "living without inhabiting himself", "dying yet I do not die" and as "soaring to the heavens". ${ }^{16}$

What is intriguing is that St Paul regarded his experience as giving him unique insight and authority, and St John of the Cross speaks of the experience as coming very rarely and to very few. What I suggest is that modern medical technology has, as it were, 'democratised' and made available to thousands an experience which has from the beginning lain at the heart of much of the world's religious perceiving and formed an important experiential basis for the future hope.

\section{Near-death Experience and the Tibetan Book of the Dead}

One of the most striking features of near-death experiences is that they are not confined to theistic traditions but appear to be common across all human cultures. In particular they appear to have played a key role in both Tibetan and Japanese forms of Buddhism. In both these Mahayana traditions we can see very close parallels between contemporary neardeath experience and that which seems to be reflected in their foundational scriptures. This has been widely noted in connection with the Bardo Thodol (The Tibetan Book of the Dead). The descriptions of what happens after death in this work correspond very closely to what contemporary near-death experiencers report. ${ }^{17}$ Consider, for example, how contemporary near-death experiencers report looking down on their bodies, observing the distress of their relatives, and the activities on the medical staff. So too in the Tibetan Book of the Dead we read that, when the person's "consciousness-principle gets outside its body", he sees his relatives and friends gathered round weeping, and watches as they remove the clothes from the body or take away the bed.

Seventy-two per-cent of contemporary near-death experiencers report seeing a radiant light which they often describe as a loving presence and sometimes name in accordance with a 
religious figure horn their own traditions. A few experience a review of their past life and many experience a range of mental images which have led many commentators to suggest that the next stage of existence could be a mind-dependent world. Once again, this is precisely what the Tibetan Book says for ii speaks of the dying person seeing the radiant, pure and immutable light of Amida Buddha before passing into what is explicitly described as a world of mental-images, in which whatever is desired is fulfilled, and in which everything that is seen is in form an hallucination reflecting the karma of the percipient.

Concerning the Being of Light which contemporary experiencers see and name in accordance with their own tradition, this also is in accord with the Tibetan Book of the Dead where we read: "The Dharmakaya (The Divine Being) of clear light will appear in what ever shape will benefit all beings". Commenting on this verse for his English translation, Lama Kazi Dawa-Samdup says, "To appeal to a Shaivite devotee, the form of Shiva is assumed; to a Buddhist the form of the Buddha Shakya Muni; to a Christian, the form of Jesus; to a Muslim the form of the Prophet; and so for other religious devotees; and for all manner and conditions of mankind a form appropriate to the occasion". ${ }^{18}$ A similar consideration applies when thinking of the vivid imagery which abounds in the Tibetan Book. These mental images are not thought of as universalisable. Rather, as Lama Anagarika Govinda points out in his introduction, "The illusory Bardo visions vary, in keeping with the religious or cultural tradition in which the percipient has grown up". ${ }^{19}$

When we examine contemporary near-death accounts this is precisely what we find. What is seen appears to be cross-cultural, but how it is named depends on the religious or nonreligious background of the believer. Thus it is only to be expected that a Christian evangelist in the Anglican Church Army would say that he had seen Jesus ${ }^{20}$ whereas the notable atheist philosopher A. J. Ayer would say "I was aware that this light was responsible for the government of the Universe". ${ }^{21}$ What matters is that both contemporary observers seem to have had an experience which had much in common.

\section{Near-death Experiences in Pure Land Buddhism}

The place where contemporary experience and foundational religious beliefs come closest together are in the scriptures and even the contemporary architecture of Pure Land Buddhism, particularly in that of the True Pureland Sect (Jodo Shinshu Buddhism). Looking first at the Scriptures, three features spring to mind. The first is that the Buddha's Pure Land seems to have many features in common with the idea of a mind-dependent world, reflecting the karma of the individual. "All the wishes those beings may think of, they will be fulfilled, as long as they are rightful". ${ }^{22}$ This idea, spelt out with many examples in the Sukhavativyuha (The Pure Land Sutra), corresponds exactly with some contemporary descriptions by resuscitated people.

The second striking feature is the experience of so many resuscitated people of seeing and being welcomed into the world beyond by a wonderful and gracious 'Being of light'. They sense that this Being knows them completely and has limitless compassion to them in welcoming them into the life beyond. We have already noted the tendency of those who see this vision to identify this Being with a religious figure from their own tradition like Jesus or Rama. But it is interesting that the descriptions given of the role of this Being do not accord with traditional expectations in the Christian or Hindu traditions but do accord with the Pureland vision of Amida Buddha as 'The Buddha of Infinite Light and Boundless Life' who has vowed to appear at the moment of death. "When they come to the end of life they will 
be met by Amida Buddha and the Bodhisatvas of Compassion and Wisdom and will be led by them into Buddha's Land". ${ }^{23}$ This combination of radiant light, wisdom and compassion corresponds precisely to the descriptions given by the resuscitated of their experience of this encounter.

A third common feature is that the imagery in which the Pure Land is described is remarkably similar to the descriptions of the land beyond given by the resuscitated. I am thinking here of the imagery in the Smaller Sukavativyuha-sutra (The Smaller Pure Land Sutra) of a wonderful garden with flowers of intense vividness of colour, of bright jewels and of "the air vibrant with celestial harmonies". ${ }^{24}$ This corresponds almost verbatim to a description given on BBC television by a young resuscitated child concerning what she saw, and I was particularly struck by the way she too stressed the intensity of the colouring of the various flowers and jewels. ${ }^{25}$ Yet the rest of the description is also very interesting - for the imagery of a beautiful garden lo describe heaven is common to all religious traditions, as is the notion of celestial music. Indeed the word 'paradise' was originally the word used for a Royal garden or park on earth.

The link between contemporary near-death experience and the Pure Land religious tradition seems exemplified in the recent building of a Great Buddha statue by the Tokyo Honganji. The statue itself was completed in 1991 and the Tokyo Honganji claim it to be the largest statue in the world. It is situated in the heart of the traditional burial grounds of the Pure Land Sect. These burial grounds are being surrounded by beautiful gardens. One is permitted to enter the Buddha statue and ascend to eye level. As one enters the lift the lights go out and one experiences the sensation of rising rapidly upwards through a tunnel of darkness till one reaches the top. Then as one leaves the lift one sees a pillar of radiant white light reaching upwards and one looks out at the world through the eyes of Buddha and what one sees is designed to evoke images of Buddha's Pure Land, and the paradise described by past and present near-death experiencers.

\section{What Contemporary Experiencers Report}

So far I have discussed the NDE in general terms and suggested that knowledge of contemporary experiences throws considerable light on key experiences of St Paul and of St John of the Cross in the Christian tradition, and on what appears in foundational Tibetan and Japanese texts in the Buddhist tradition. I propose now to look in more detail at the largest and most detailed survey of contemporary experiences, to see what these tend to have in common and what the impact on the experiencer usually is.

Since the pioneering works of Raymond Moody and J. C. Hampe, published independently of each other in the USA and Germany in the early seventies ${ }^{26}$, there have been a flood of individual accounts, scientific surveys and television documentaries. ${ }^{27}$ Most of these are based on relatively small samples of between 50 and 100 cases, but recently Peter and Elizabeth Fenwick have published a comprehensive survey based on 344 British experiencers all of whom filled in a detailed questionnaire as well as writing a long personal account ${ }^{28}$. This survey probably gives us the fullest account available yet of what are the characteristic features of a near-death experience.

What is immediately apparent is that the near-death experience carries with it very strong positive emotions. In the Fenwicks' survey $82 \%$ felt calmness and peace, $40 \%$ felt joy and $38 \%$ felt love. Individuals wrote in glowing terms of their feelings, some speaking of utter 
peace and complete happiness: "no person could experience such joy" and "I was filled with elation". Many felt that they were at peace because they understood everything: "I was peaceful, utterly content, I knew the light held all the answers".

For many people the experience of the transforming light was the most profound emotional experience they have ever had. Their feeling was of being overwhelmed with universal love, of being accepted by some loving being. This led a high proportion of the percipients (72\%) to feel that they had been changed by the experience; $42 \%$ felt that they had become more spiritual as a result, $22 \%$ talked of becoming 'better persons' and $40 \%$ described themselves as more socially conscious. Many speak of every day as a new gift, and feel they should live life more fully and purposefully. One intriguing fact is that $47 \%$ of those who have neardeath experiences felt themselves to be more psychically sensitive. By this is meant feelings of being able to predict the future, or to possess powers of healing the sick. Clearly it would be useful to check such claims to see if there is any empirical evidence to support them. But it is at least worth noting that such beliefs often follow other deeply felt religious experiences which suggests again that the NDE falls into this kind of category.

Another feature which NDEs have in common with other kinds of religious experience is that they are not always positive experiences. Almost $1 \%$ talked of a hellish experience, $15 \%$ felt a sense of fear, and $9 \%$ a sense of loss. These figures are in line with other contemporary surveys, but out of line with reports from earlier cultures where hellish experiences were very much more commonly reported. ${ }^{29}$ Once again this is a feature which NDEs share with contemporary religious experience which tends to focus on a sense of the love of God while earlier generations talked more commonly of a sense of fear. In both cases, however, there has always been a spectrum of positive and negative experiences which might justify the speculation that beliefs about both heaven and hell may have a basis in such experiences.

On matters of religious belief, most of the Fenwicks' respondents felt that their religious outlook had been broadened rather than simply confirmed. In their responses there was a tendency to speak of feeling in the presence of a higher Being, rather than talking of God, and in the British sample Jesus or Mary were only rarely named. The dominant characteristic was a sense of spiritual awakening which sometimes felt uneasy at any continuing acceptance of a narrow doctrinal system. There was a sense that the Reality glimpsed was of more universal significance than simply to one's inherited tradition. Again, this is a characteristic of experientially based religious beliefs in that mystics of all traditions tend to feel closer to one another than do those who base their belief-system more strongly on an inherited tradition.

For purposes of this paper, one of the most intriguing and perplexing aspects of the Fenwicks' survey was the impact a near-death experience has on the experiencers' attitude to death. On the one hand the most common effect of all was that $82 \%$ said they now had less fear of death. On the other hand this does not necessarily mean that they had come to a clear belief in a life after death, for $48 \%$ said they did not believe in personal survival.

This is further complicated by the fact that some who held this view also thought that some important part of them, their consciousness or soul, might yet continue. What this suggests to me is that an NDE can strongly encourage belief in a future life and for many this is the most important fact about their NDE; but it is not a necessary consequence of the experience, and cannot over-ride strongly held philosophical beliefs - as we shall see below in relation to A. J. Ayer. 


\section{Near-death Experiences, Heaven and Hell}

These findings of Peter and Elizabeth Fenwick are very much in line with the findings of other researchers in other countries. Carl Becker (Professor of Comparative Thought at Kyoto University) remarks how reminiscent modem NDEs are to accounts in Chinese and Japanese literature concerning "those who have been to heaven and back", ${ }^{30}$ and he notes also that surveys in India and America among Christians, Jews and Hindus all present closely similar reports. J. C. Hampe in Germany comes to the same conclusion. ${ }^{31}$ The experience seems to cut across all cultural and religious boundaries and yet to present the archetypal imagery of a paradisal heaven of flowery gardens, suffused in warm light and radiant with peace and joy and in the loving presence of a Being of light, of love and of compassion. However the few negative experiences also echo archetypal imageries of hell. It seems overwhelmingly likely that reports from past near-death experiences are what have shaped our traditions and provided the content of our religious imagery concerning the future life.

These considerations are why I suggest that the experiential foundation for belief in a future life derives both from religious experience of a relationship with God, and from the reports of people who, near the frontier of death, believe they have caught a glimpse of a life beyond.

\section{The Problem of Analysing Near-death and Religious Experiences}

If one tries to see any pattern in this data, it does seem that to classify NDEs under the heading 'contemporary religious experience' makes good sense. It shares the ambiguity of all religious experience in that the boundaries are fuzzy and what is true of the majority of cases is not true of all. Like all religious experiences, what convinces the percipient does not necessarily influence the thinking of one who is merely told of another's experience. And, while the Fenwicks' survey throws useful light on the subjective feelings of people who have NDEs, this does not solve the question of what (if any) may be the explanation we give to such phenomena.

For me one of the most impressive features of the NDE is the profound effect it has on the majority of those who experience it. Long ago William James argued that religious experiences are real because they have real effects. In the case of the NDE this is particularly noticeable. As we saw in the survey quoted above, $72 \%$ felt their lives transformed. Comparable findings have been confirmed by others. Bruce Greyson, Editor of Near-death Studies and a Professor of Psychiatry, sums up the data thus: "It is the most profound experience I know of ... nothing affects people as strongly as this". ${ }^{32}$ This is further endorsed by Kenneth Ring in his book Life at Death which shows that the most impressive feature of the near-death experience is the impact it has on the beliefs and attitudes of those who have them. ${ }^{33}$

Of course, as with all such experiences, the impact is not epistemically coercive, so that it remains possible for a person to be unpersuaded by it. This is both illustrated and illuminated by the impact his NDE experience had on A. J. Ayer. His first response was to think that, "on the face of it, these experiences are rather strong evidence that death does not put an end to consciousness". However after rehearsing some of the philosophical problems associated with life after death, his conclusion was more modest: namely that "my recent experiences have slightly weakened my conviction that my genuine death, which is due fairly soon, will be the end of me, though I continue to hope it will". Later he retracted even this but, from a person with his long and carefully thought-out position, his testimony to the power of the initial experience remains striking. ${ }^{34}$ 


\section{An Important Research Project}

From a scientific perspective, one feature which is a permanent difficulty in the way of investigating topics like religious or near-death experiences is that the most one can normally do is to collect and analyse subjective reports. But at least we can now do this on a massive scale. Carl Becker has pointed out that the availability of modern computerised storage and comparison enables thousands of such cases to be collected from all over the world and analysed together. There is certainly value in such a project for - if it could be totally established that thousands of people from totally disparate cultures, world-views and backgrounds have all reported a common set of experiences near the point of death - this does at least provide some grounds for supposing that this might actually be what happens at that point. As Richard Swinburne suggests, "in the absence of special considerations", "how things seem to be is good grounds for a belief about how things are". ${ }^{35}$

But there is a problem in applying this to the claim that near-death experiences show that at death the soul goes out of the body and moves on to a new mode of existence, as so many NDE experiencers believe. The problem is precisely the existence of such 'special considerations' - namely the mass of evidence that human consciousness cannot possibly subsist except within a functioning physical brain. But if it could ever be established that this 'limiting principle' did not apply, then this barrier against taking NDEs as evidential of survival would not apply.

One intriguing fact about the NDE is that many who report "going out of the body" at the time of apparent death, not only enjoy mystical experiences such as we have already described but also claim to "look down from above" on the resuscitation attempts, and are incredibly accurate in the observations they subsequently report which turn out to be correct in terms of what a person would have seen if he or she really had been viewing from the ceiling.

These facts are accepted even by that most resolutely sceptical of the NDE inquirers, Susan Blackmore. She accepts that "there is no doubt that people describe reasonably accurately events that have occurred around them during their NDE". However, she suggests that a combination of "prior knowledge, fantasy, and lucky guesses and the remaining operating senses of hearing and touch" may provide the information for the images seen which are viewed autoscopically from above because that is the perspective from which we see ourselves in memory. ${ }^{36}$ People who actually have the experience always see such explanations as alien 'hetero-interpretations' which fail to account for the way it actually seems to them. And the very large number of correct observations which do not fit into any of Blackmore's explanatory categories (other than the catch-all category of 'lucky guesses'), suggest that the data cannot easily be accommodated in so narrow a Procrustean bed.

However this issue could actually be resolved if a large enough prospective survey could be done in hospital contexts where it could be established on a non-anecdotal basis whether or not correct observation actually took place of a kind that could not be accounted for by any 'natural' means. For this to happen would require the collaboration of medical staff and hospital administrators in the placing of objects in cardiac wards and casualty units which could only be seen and described by an agent actually looking down from the ceiling. Such a project would be fully scientific in that it offers a proposal that is in Popperian terms falsifiable. On average, $10 \%$ of people admitted to a cardiac ward can be expected to have a near-death experience and well over half of these will report an autoscopic experience. If, out of a hundred such patients, none mentions seeing the objects, one could safely conclude that 'seeing' from out-of-the-body does not occur and that NDEs are only subjectively real. 
But if a number of cases of correct 'seeing' could be proven beyond dispute, the principle that consciousness can exist outside the body would have been established, and one roadblock across the path of belief in immortality would be removed.

Such a project is not impossible to establish since Peter Fenwick and I did successfully negotiate a pilot study in two hospitals during a 2-year period. However, the handful of cases that occurred in this time did nothing but confirm the sad fact that most people resuscitated from a close encounter with death actually die without ever regaining sufficient strength to be interviewed about what (if anything) they experienced. However, if such a prospective study could be undertaken over a large enough number of Hospitals for a sufficiently long time to build up a worthwhile data base, the truth or falsity of the claim that near-death experiences provide evidence that consciousness can exist apart from the body - could be established. Whatever the result of the experiment it would be good to know the answer!

\section{Conclusion}

The question of whether or not there is a life after death is potentially the most important issue that could be raised. What I have sought to show in the paper is that, like most of the things we believe about the nature of reality, our answers to this question depend at least in part on our experiencing. A person who believes that they have truly encountered a personal and loving God, perhaps identified as the Risen Christ, is likely to believe that they have an eternal destiny. Likewise, a person who has had a profound near-death experience may also come to such a belief. In neither case is the experience epistemically coercive and many will conclude that like so much else about our world the data is ambiguous and capable of a range of alternative explanations.

However in the case of near-death experiences there is the tantalising prospect that future research could tip the balance of probability one way or the other. Let us hope that this challenge will be taken up so that we may know whether mortality or immortality is to be our ultimate end!

\section{NOTES}

1. Basil Mitchell, The Justification of Religious Belief, London: Macmillan 1973: Richard Swinburne, The Existence of God Oxford: OUP 1979: John Hick, An Interpretation of Religion London: Macmillan 1989.

2. 2 Samuel 14:14, Job 20:7, Genesis 2:7, Isaiah 14:11, Psalm 146:4.

3. John Bowker, The Meanings of Death, Cambridge: CUP 1991 p.30

4. Ecclesiastes 3:19, Psalm 90:5.

5. Wheeler Robinson, Inspiration and Revelation in the Old Testament, Oxford University Press 1962 p. 103

6. Edward Schillebeeckx, Christ, the Christian Experience in the Modern World, London: SCM 1980 p.797

7. St Athanasius, On the Incarnation ch.30, London: Mowbray 1963, pp.60-61

8. David Hay, Religious Experience Today, London: Mowbray 1990 p.59. 
9. According to E. Kubler-Ross, On Life after death, Berkeley: Celestial 1991 p.47. Carl Becker has a database of "thousands of such cases" (Becker, Paranormal Experience and Survival of Death, New York: Suny 1993 p.77.

10. Mircea Eliade, "Mythologies of Death" in F. E. Reynolds \& E. H. Waugh, Religious Encounters with Death, Pennsylvania University Press, 1977, p. 17

11. Daniel Van Egmond, Body, Subject and Self: The possibilities of survival after death, Utrecht University Press 1993 p. 15.

12. D. Shiels, "A cross-cultural study of beliefs in out-of-the-body experiences", Journal of the Society for Psychical Research Vol 49, No 775, (March 1978) p.699.

13. 2 Corinthians $12: 1-5$

14. 2 Corinthians 12:7.

15. St John of the Cross, The Dark Night of the Soul Bk.2 Ch.24. tr. by Kurt Reinhardt, London: Constable 1957 p. 84.

16. St John of the Cross, Poems, tr. by Roy Campbell, Penguin 1960 p.51 (all from 47-57 are relevant). That secular love poems of that time use the phrase "dying that I do not die" as a sexual metaphor does not prevent us from supposing that St John was using the expression in its primary sense.

17. W. Y. Evans-Wentz (ed.), The Tibetan Book of the Dead or the After-Death Experiences on the Bardo Plane, according to Lama Kazi Dawa-Sumdup's English Rendering, 1927 3rd Edition OUP 1957, pp.98, 101.

18. The Tibetan Book of the Dead p.94.

19. Introduction to the Tibetan Book of the Dead p.Ixii.

20. BBC Television Everyman programme "At the Hour of Death", March 1982.

21. A.J. Ayer, "What I saw when I was dead" in Paul Edwards, Immortality, New York: Macmillan, 1992.

22. Edward Conze, Buddhist Scriptures, Penguin, 1959, p.233 (part of a series of extracts from the Sukhavativyuha 15-19, 21-22, 24, 26-27).

23. Bukyo Dendo Kyokai, The Teaching of Buddha, Tokyo Buddhist Promoting Foundation 1980 p.218 quoting from Amitayurdhyana-sutra.

24. The Teaching of Buddha, p. 220.

25. BBC Television Everyman programme, "At the Hour of Death" March 1982 (The description also occurs in print in Thomas Smith, "Called back from the dead", in Pulse, 19th July 1980.)

26. R. A. Moody, Life after Life, Atlanta: Mockingbird 1973; J. C. Hampe, To Die is Gain, 1975 in Germany, English translation London: Darton, Longman and Todd, 1979

27. See for example the works of K. Ring and Carl Becker cited below and for fuller information consult the bibliographies in Susan Blackmore, Dying to Live, London: Grafton, 1993 and Peter and Elizabeth Fenwick, The Truth in the Light, London: Headline, 1995.

28. Peter and Elizabeth Fenwick, The Truth in the Light, London: Headline, 1995 and summarised in "The near-death experience" in Paul Badham and Paul Ballard, Facing death, Cardiff: University of Wales Press, 1996. All details that follow derive from this chapter.

29. Cf. Bede, A History of the English Church and People, Book V chapter 12, first published 731, Harmondsworth: Penguin 1962, pp.284-9. See also Carol Zaleski, Otherworld Journeys, Oxford University Press 1987. 
30. Carl Becker, Paranormal Experience and Survival of Death, State University of New York 1993, pp.90-91. cf also his earlier article, "The Pure Land Revisited: Sino-Japanese Meditations and Near-Death Experiences of the Next World", Journal of Near-Death Studies 4, no 1 (1984): 51-68.

31. J. C. Hampe, To Die is Gain, Darton Longman and Todd, 1979

32. Cited in Mick Brown, "Life after Death", The Daily Telegraph 27th March 1993, Magazine section p. 21.

33. Kenneth Ring, Life at Death: A Scientific Account of the Near-death Experience, New York: Coward, McCann \& Geohagen, 1980, pp.81, 169, 240.

34. A.J. Ayer, "What I saw when I was dead" in Paul Edwards, Immortality, Macmillan 1992.

35. Richard Swinburne, The Existence of God, Oxford: Clarendon, 1979 p.254.

36. Susan Blackmore, Dying to Live: Science and the Near-death Experience, London: Grafton, 1993, p. 114-1 15.

\section{THE AUTHOR}

Professor Paul Badham has been Head of the Department of Theology and Religious Studies at University of Wales Lampeter since 1991. He was born in 1942 and educated at Jesus College Oxford (traditional Christian Theology); at Jesus College Cambridge (Modern Religious Thought); and at Westcott House (Anglican Ministry). He then went to Birmingham and for five years worked as a Curate while simultaneously writing a PhD under John Hick. Since 1973 he has been at Lampeter where he has gradually moved from Lecturer to Senior Lecturer to Reader and finally to Professor and Dean.

On his arrival at Lampeter he joined five other Anglican clergymen in a very traditional Department of Theology. One of his main concerns has been to transform the Department into a vibrant centre for the study of all world religions, with a particular emphasis on religion in the contemporary world and with an emphasis on the possibility of studying each religion from within. The Department now consists of 18 full-time and 12 part-time staff across the whole area of Religious Life and Thought, with specialists in each of the major faiths and with all disciplines of Religious Studies included.

Exploration of the arguments for and against belief in a life after death has been one of Paul Badham's main academic concerns. This led to his books Christian Beliefs about Life after Death and Immortality or Extinction? as well as to his edited collections Death and Immortality in the Religions of the World; Perspectives on Death and Dying; Ethics on the Frontiers of Human Existence and Facing Death. He has for many years directed a unique MA programme on Death and Immortality, taught jointly with the Philosophy Department at Lampeter, and he has always had a succession of research students working in this area from all over the world. He has contributed to seven television documentaries on the Near-death experience and is currently preparing for a major international conference on this in Washington.

Paul Badham is also deeply interested in issues of Modern Theology and Inter-faith Dialogue, and has contributed to a series of books in this area arising from Conferences in Claremont as well as his edited John Hick Reader. He has also written a series of bilingual (England and Japanese) publications with Professor Daigan Lee Matsunaga on Near-Death Experiences, Interfaith 
Dialogue and Christian Beliefs About God and Christ in Relation to True Pure Land Buddhism (published in Japanese as Christianity for Buddhists). He is currently working on a Centenary volume for the Modern Church People's Union on The Contemporary Challenge of Modernist Theology.

Paul Badham's other concern is the relationship between Religion and Politics. This has led to his edited work Religion, State and Society in Modern Britain and to an ongoing project with Vladislav Arzenukhin on Religion and Change in Eastern Europe. This concern also helped to establish an MA degree on Religion Politics and International Relations, jointly taught by the Department of Theology and Religious Studies at Lampeter and by the Department of International Politics at Aberystwyth.

RERC Second Series Occasional Paper 13

August 1997

Copyright (C 1997 Religious Experience Research Centre

ISBN 0906165210 